\title{
Chemical Composition of Milk Obtained from Holstein Friesian Cows during First and Second Lactation
}

\author{
Gordana Dimitrovska ${ }^{1}$ \\ ${ }^{1}$ Department of Food Technologies, University "St. Kliment Ohridski”- Bitola, \\ Faculty of Biotechnical Sciences, North Macedonia
}

\begin{abstract}
In this study milk samples from Holstein Friesian cows were collected and analyzed during the first and second lactation period in a period of six months. The following parameters have been examined: protein content, fat content, lactose, and dry matter in milk. The average values of the content of milk protein, fat, lactose and dry matter in the milk of first lactation were as following: $3,14 \%, 3,25 \%, 4,46$ $\%, 11,48 \%$ and in the milk of second lactation are: $3,21 \%, 3,29 \%, 4,39 \%$ and $11,68 \% . \%$. Milk from cows in the second lactation had a higher concentration of protein, more fat and dry matter than cow's milk from the first lactation.
\end{abstract}

Key Words: quality, chemical composition, milk, lactation, breeds

\section{INTRODUCTION}

Raw milk quality is a term with a very broad meaning, Czerniewicz et al., (2006). It encompasses such milk characteristics as chemical composition, physical properties, microbiological and cytological quality, sensory properties, technological suitability and nutritive value. It is very difficult to assure high quality and desirable physicochemical properties of raw milk designed for processing, since this is dependent on numerous factors, including genetic ones (e.g. breed).

Dairy cows experience many physiological changes at parturition and produce the secretion in the mammary gland immediately following parturition. Their secretion is classified as colostrum, transition milk, and milk in the function of time after calving. Milk and dairy products play an important role in having high nutritional value as the animal food source and positive influences on human health as well (Dong-Huam Lin et al., 2020).

Changes in milk composition throughout lactation have been studied extensively, however, very little is known about the composition of milk produced during the first and second lactation. A lot of genetic and paragenetic factors have a significant influence on the changes in the total count of somatic cells and the chemical composition of milk. The most important factors that affects this changes are as following: breed, the stadium of lactation, the cycle of lactation, cow's age, the time of the year, the way of cow's holding and diet, infection of the udder, way of milking, the quality of milking system and also the education of the milk-producers. Ambient conditions, the microclimate in which the animal lives influents on the health condition of the animal.

According to some authors studies, clean, dry, and comfortable environment, the commodity of cows, good ventilation and everyday cleaning, helps a lot to minimize the contamination of cow's udder and reduces the appearance of mastitis and other infective diseases (Menries Fraser and Mackie Dermont P., 2001).

In order to produce milk with a lower number of somatic cells and bacteria, Garsia, (2004) in his studies indicates two 
key factors: cleaning and adequate hold and transport of the milk.

Yayaro et al., (2004); Zrinka Cacic et. al., (2003) concluded that the somatic cells and total count of bacteria in milk might be indicators for breed control, health udder of the animal, and milk quality.

\section{MATERIALS AND METHODS Materials}

Holstein Friesian cows (12) in the first lactation and (12) cows in the second lactation were taken in the study. The examined samples were taken in the postcolostrum period in the first six months of lactation.

The cows were raised in controlled conditions on a cattle farm with a capacity of about 860 cows in the same care and nutrition conditions. Milking was performed by machine - automatically with Duovak 400 DE Laval, and the samples were taken from a vector - milk meter. Milking was performed twice at 12-hour intervals. The milk is transported through milk pipes that are installed in the Barn and outside it to a collection dairy. Until transportation to the dairy, the milk was kept at $\mathrm{t}=4^{\circ} \mathrm{C}$ in two De Laval milk freezers with a capacity of 7,800 litres. The average daily milk production on the farm was about 14,000 liters.

\section{Methods \\ Determination of chemical composition}

The chemical analysis of all milk samples were made twice in a month. All chemical analysis of milk (determination of fats, proteins, lactose and dry matter) were made on a high-precision infrared analyzer LACTOSCOPE.

\section{Statistical analysis}

Each parameter was determined after three repetitions, and the results are presented as mean value $\pm \mathrm{Sd}$. The obtained results are mathematically and statistically processed in Microsoft Excel.

\section{RESEARCH RESULTS}

The results from the average protein content in the chemical composition of Holstein Friesian cows during the first and second lactation are presented in Table 1.

Table1 Protein content (\%) in milk during I and II lactation

\begin{tabular}{|l|l|l|l|l|l|l|l|}
\hline \multirow{2}{*}{ Months } & \multirow{2}{*}{$\mathbf{N}$} & \multicolumn{1}{|c|}{ I lactation } & \multicolumn{1}{|c|}{ I lactation } \\
\cline { 3 - 8 } & & $\overline{\boldsymbol{x}}$ & $\mathbf{s}$ & $\boldsymbol{C v}(\boldsymbol{\%})$ & $\overline{\boldsymbol{x}}$ & $\mathbf{s}$ & $\mathbf{C v}(\boldsymbol{\%})$ \\
\hline 1 & 12 & 2,8443 & 0,1267 & 4,46 & 2,9048 & 0,2939 & 10,12 \\
\hline 2 & 12 & 2,9435 & 0,2203 & 7,48 & 2,9675 & 0,2766 & 9,32 \\
\hline 3 & 12 & 3,0318 & 0,1189 & 3,92 & 3,0438 & 0,2921 & 9,6 \\
\hline 4 & 12 & 3,0792 & 0,1224 & 3,97 & 3,0382 & 0,2888 & 9,5 \\
\hline 5 & 12 & 3,4717 & 0,285 & 8,21 & 3,5668 & 0,2437 & 6,83 \\
\hline 6 & 12 & 3,4807 & 0,2816 & 8,09 & 3,7838 & 0,5554 & 14,68 \\
\hline Total values & 72 & 3,1418 & 0,3186 & 10,14 & 3,2175 & 0,4699 & 14,6 \\
\hline
\end{tabular}

In Table 1 the average protein content (\%) by months is presented. According to the results it can be concluded that in the herd during the first lactation the protein content varies from 2.84 to $3.48 \%$, with the coefficient of variation ranging from 3.92 to $8.21 \%$. In the second lactation in the herd, the average protein content ranges from $2.90 \%$ to $3.78 \%$, with the coefficient of variation ranging from 6.83 to $14.68 \%$.

From the results, it can be noticed that the herds in both lactations tend to increase the percentage of protein, which is due to the increase use of protein foods in the diet of the cows. The average values in the herd of the first lactation was $3.14 \%$ and in the herd of the second lactation was $3.21 \%$, which confirms that they are close and we can conclude that the percentage of protein largely depends on genetic factors, but in this case also on paragenetic factors (from diet). There are differences in the percentage of protein in the fifth and sixth months but they are insignificant.

Similar reports about protein content as compound of the chemical composition, during the early lactation from Holstein 
daily cows were found by Dong-Hyun Lim et al.,(2020); Delaby et al., (2009).

The results from the average fat content in the chemical composition of
Holstein Friesian cows during the first and second lactation are given in Table 2 .

Table 2: Fat content $(\%)$ in milk during I and II lactation
\begin{tabular}{|l|l|l|l|l|l|l|l|}
\hline Months & $\mathbf{N}$ & \multicolumn{1}{|c|}{ I lactation } & \multicolumn{1}{c|}{ II lactation } \\
\cline { 3 - 8 } & & $\bar{x}$ & $\mathbf{s}$ & $\boldsymbol{C v}(\boldsymbol{\%})$ & $\bar{x}$ & $\mathbf{s}$ & $\mathbf{C v}(\boldsymbol{\%})$ \\
\hline 1 & 12 & 3,0974 & 0,5106 & 16,48 & 3,189 & 0,4583 & 14,37 \\
\hline 2 & 12 & 3,0437 & 0,4802 & 15,78 & 3,1238 & 0,4057 & 12,99 \\
\hline 3 & 12 & 3,0493 & 0,3712 & 12,17 & 3,1241 & 0,6494 & 20,79 \\
\hline 4 & 12 & 3,1627 & 0,1932 & 6,11 & 3,4213 & 0,6713 & 19,62 \\
\hline 5 & 12 & 3,5259 & 0,5385 & 15,27 & 3,566 & 0,658 & 18,45 \\
\hline 6 & 12 & 3,6323 & 0,7964 & 21,92 & 3,6352 & 0,4857 & 14,43 \\
\hline Total values & 72 & 3,2519 & 0,5507 & 16,93 & 3,3432 & 0,5697 & 17,27 \\
\hline
\end{tabular}

The average fat content (\%) per month in the herd from the first lactation varies from $3.04 \%$ to $3.63 \%$, with the coefficient of variation ranging from 6.11 to $21.92 \%$. The average fat content of the herd in the second lactation varies from 3.12 to $3.63 \%$ where the coefficient of variation ranges from 12.99 to $20.79 \%$.

This tendency is a result of the later lactation period in which the herd and the diet are located, i.e. in the first, second, and the third month of the examinations (spring) the percentage of green food is higher (indicated, with a higher $\%$ of water), for the remaining three months, foods with a higher percentage of dry matter were used.

From the presented data it can be noticed that the average fat content in the herd in the first lactation is $3.25 \%$ and in the herd in the second lactation $3.29 \%$. The differences are small and insignificant, but still, there are slightly higher values as a result of the higher consumption of dry matter in the herd during the second lactation.

Gurmessa \& Melaku 2012, reported that fat content of the milk was significantly higher $(\mathrm{p}<0,05)$ in early and late than mid stage of lactation, which is confirmed from the results.

The average mean values of lactose in $\%$ are shown in Table 3.

From the results it can be seen that lactose content $(\%)$ as part of the chemical composition of milk, in herd in the first lactation varies from $4.39 \%$ to $4.54 \%$ where the coefficient of variation ranges from 1.86 to $5.66 \%$. In herd in the second lactation, the average lactose content ranges from 4.29 to $4.39 \%$, with the coefficient of variation ranging from 2.93 to $5.05 \%$.

From the first to the third month there is a tendency of increase the values of lactose in both lactations, and in the fourth, fifth and sixth month there is a smaller tendency of decrease.

Decreasing lactose content (\%) in the fifth and sixth months is due to the physiological course of lactation on the one hand and on the other hand as a result of the increased number of somatic cells in these months where lactose appears as the first indicator, and thus more identified mastitis in that period.

Table 3: Lactose content (\%) in milk during in I and II lactation

\begin{tabular}{|l|l|l|l|l|l|l|l|}
\hline \multirow{2}{*}{ Months } & \multirow{2}{*}{$\mathbf{N}$} & \multicolumn{2}{|c|}{ I lactation } & \multicolumn{1}{c|}{ I lactation } \\
\cline { 3 - 8 } & & \multicolumn{2}{|c|}{$\mathbf{s}$} & $\boldsymbol{C v}(\boldsymbol{\%})$ & $\overline{\boldsymbol{x}}$ & $\mathbf{s}$ & $\mathbf{C v}(\boldsymbol{\%})$ \\
\hline 1 & 12 & 4,4425 & 0,0957 & 2,15 & 4,3693 & 0,1696 & 3,88 \\
\hline 2 & 12 & 4,3997 & 0,0906 & 2,06 & 4,2926 & 0,206 & 4,8 \\
\hline 3 & 12 & 4,543 & 0,1095 & 2,41 & 4,4883 & 0,2268 & 5,05 \\
\hline 4 & 12 & 4,5463 & 0,0847 & 1,86 & 4,4308 & 0,2046 & 4,62 \\
\hline 5 & 12 & 4,4128 & 0,2497 & 5,66 & 4,4045 & 0,1291 & 2,93 \\
\hline 6 & 12 & 4,4018 & 0,2075 & 4,71 & 4,3959 & 0,1603 & 3,65 \\
\hline Total values & 72 & 4,4577 & 0,1613 & 3,62 & 4,3969 & 0,1888 & 4,29 \\
\hline
\end{tabular}


Gordana Dimitrovska. Chemical composition of milk obtained from holstein friesian cows during first and second lactation.

Dry matter $(\%)$ content in chemical composition of milk from Holstein Friesian cows during I and II lactation are presented in Table 4.

Table 4: Dry matter (\%) in milk during I and II lactation

\begin{tabular}{|l|l|l|l|l|l|l|l|}
\hline Months & \multirow{2}{*}{$\mathbf{I}$} & \multicolumn{1}{|c|}{ I lactation } & \multicolumn{3}{|c|}{ I lactation } \\
\cline { 3 - 8 } & & $\boldsymbol{x}$ & $\mathbf{s}$ & $\boldsymbol{C v}(\boldsymbol{\%})$ & $\overline{\boldsymbol{x}}$ & $\mathbf{s}$ & $\mathbf{C v}(\boldsymbol{\%})$ \\
\hline 1 & 12 & 10,9919 & 0,5312 & 4,83 & $\overline{\boldsymbol{X}}, 1465$ & 0,6372 & 5,72 \\
\hline 2 & 12 & 11,0285 & 0,6019 & 5,46 & 11,3594 & 1,056 & 9,3 \\
\hline 3 & 12 & 11,279 & 0,3819 & 3,39 & 11,3979 & 0,854 & 7,49 \\
\hline 4 & 12 & 11,434 & 0,2338 & 2,04 & 11,6801 & 0,795 & 6,81 \\
\hline 5 & 12 & 12,0938 & 0,7336 & 6,07 & 12,2128 & 0,7233 & 5,92 \\
\hline 6 & 12 & 12,0806 & 0,7544 & 6,24 & 12,2623 & 0,7567 & 6,17 \\
\hline Total values & 72 & 11,4846 & 0,7134 & 6,21 & 11,6765 & 0,8947 & 7,66 \\
\hline
\end{tabular}

From the results presented in Table 4, which refer to the percentage of dry matter in herds in the first and second lactation, it can be concluded that in the first lactation, the average content varies from $10.99 \%$ to $12.09 \%$, where the coefficient of variation ranges from $2.04 \%$ to $6.24 \%$. In the herd in the second lactation, the average content varies from $11.14 \%$ to $12.26 \%$, with the coefficient of variation ranging from $5.72 \%$ to $9.3 \%$.

Comparing the values of dry matter from both lactations, a tendency of a constant increase of the percentage of dry matter from the first to the sixth month can be noticed. This tendency is physiologically expected and is within the normal range.

The average values of dry matter in the second lactation are somewhat higher as a result of the higher values of other ingredients that are part of the milk (protein, fat). Similar results about content of dry matter in the chemical composition of milk from the Holstein Friesian cows during lactation were found by Yoo J. et al., (2019); Stoop WM et al., (2009); Horan B, et al., (2005); Coleman J. et al.,(2010).

\section{CONCLUSION}

Based on the examination made during the period of six months, lactation and results from examined parameters from the milk of Holstein Friesian cows the following conclusions are obtained:

Milk obtained from Holstein Friesian cows was characterized with good quality, which indicated good sanitary and husbandry conditions.
The average values of the content of milk protein, fat, lactose and dry matter in the milk of first lactation are: $3,14 \%, 3,25 \%$, $4,46 \%, 11,48 \%$ and in the milk of second lactation are: $3,21 \%, 3,29 \%, 4,39 \%$ and $11,68 \%$. The milk provided from cows in the second lactation had a higher concentration of protein, more fat and dry matter than cow's milk from the first lactation.

The properties of milk from cows of Holstein Friesian breed, analyzed in the experiment, showed typical values, consistent with the relevant requirement specified in legal regulations.

Therefore, the current study suggests that milk from Holstein Friesian cows in the second lactation is more efficient in processing dairy products compared to Holstein milk from the first lactation, under the same environmental and dietary conditions.

Acknowledgement: None

\section{Conflict of Interest: None}

\section{Source of Funding: None}

\section{REFERENCES}

1. Coleman J, Pierce KM, Berry DP, Brennan A, Horan B. 2010. Increasing milk solids production across lactation through genetic selection and intensive pasture-based feed system. J Dairy Sci.93:4302-17.

2. Cacic Z., Kalit S., Cacic M., 2003. Somatske stanice i cimbenici koi utjecu na njihov broj u mlijeku. Mlekarstvo 53 (1) 23 36, Zagreb, Croatia. 

second lactation.

3. Czerniewicz, Maria, Katarzyna Kielczewska, Antoni Kruk 2006. Comparison of some physicochemical properties of milk from Holstein-Friesian and jersey cows. Polish journal of food and nutrition sciences, Vol. 15/56, SI 1, pp. 6164.

4. Dong-Hyun Lim, Vijayakumar Mayakrishnan, Hyun-Jeong Lee, KwangSeok Ki, Tae-I Kim and Younghoon Kim. 2020. A comparative study on milk composition of Jersey and Holstein dairy cows during the early lactation. J Anim Sci Technol 2020; 62(4):565-576.

5. Delaby Luc, Philippe Faverdin, Guillaume Michel, Catherine Disenhaus, Jean Louis Peyraud, 2009. Effect of different feeding strategies on lactation performance of Holstein and Normande dairy cows. Animal, 3:6, p 891-905.

6. Garsia Alvaro D. 2004. Somatic cells and high bacteria counts: How to deal with them. Dairy Science, 4031.

7. Gurmessa Jemila and Achenef Melaku, 2012. Effect of Lactation Stage, Pregnancy, Parity and Age on Yield and Major Components of Raw Milk in Bred Cross Holstein Friesian Cows. World Journal of Dairy \& Food Sciences 7 (2): 146-149, 2012 ISSN 1817-308X

8. Horan B, Dillon P, Faverdin P, Delaby L, Buckley F and Rath M 2005. The interaction of strain of Holstein-Friesian cows and pasture-based systems on milk yield, body weight and body condition score. Journal of Dairy Science 88, 12311243.

9. Jayarao B.M., Pillai S.R., Sawant A.A., Wolfgang D.R. and Hegde N.V. (2004). Guidelines for monitoring Bulk Tank Milk Somatic Cell and Bacterial counts. Journal of Dairy Science 87: 3561-3573.

10. Menzies Frazer D. and Mackie Dermot P 2001. Bovine toxic mastitis risk factors and control measures. Irish Veterinary Journal volume 54: 30-37.

11. Stoop WM, Bovenhuis H, Heck JML, Van Arendonk JAM. 2009. Effect of lactation stage and energy status on milk fat composition of Holstein-Friesian cows. J Dairy Sci.;92:1469

12. Yoo J, Song M, Park W, Oh S, Ham JS, Jeong SG, 2019. A comparison of quality characteristics in dairy products made from Jersey and Holstein milk. Food Sci Anim Resour, 39:255- 65.

How to cite this article: Dimitrovska G. Chemical composition of milk obtained from holstein friesian cows during first and second lactation. International Journal of Research and Review. 2021; 8(6): 382-386. DOI: https://doi. org/10.52403/ijrr.20210648 